For the past two years I have been the medical officer on this isolated South Atlantic island and have had to practise a certain amount of dentistry. Here one would see how successful preventive dentistry could confer a wonderful benefit on the islanders. I have performed 176 extractions and 50 fillings over the past two years. Mr. J. Fisher, of University of Birmingham Dental School, who recently came on the Medical Research Council project on the health of the islanders, performed 216 extractions and 336 fillings. The extractions were carried out for caries in children and for caries and periodontal disease in adults. Mr. Fisher has stressed that there is still a great deal of potential dental disease and that the situation will become progressively worse. On Tristan, at any rate, the cause is certainly not a change from cold to hot food and drink as Dr. Taylor would suggest. In fact, the islanders seem to prefer their drinks and food rather cold or just warm.

The whole situation has tempted me to consider my own upbringing and my relatively perfect teeth. I grew up in Pakistan with plenty of sunshine and, like my parents, brothers, and sisters, have caries-free teeth. Our food was always cooked at home, rarely factory processed or tinned. In the six-month season I chewed sugar-cane every day, perhaps as much as 3-4 full-length canes, rather than use a toothbrush. This provided plenty of masticatory exercise and tooth cleansing. The only sweets I had were in the form of lumps of unrefined sugar made from cane-i.e., sugar-cane juice that has cooled off. Incidentally, there is only one Tristan da Cunha child whose deciduous teeth at the age of $4^{1 / 2}$ are completely caries-free, and his gums are also very healthy (unlike those of the other children here of his age). His mother says that, unlike the other children, he does not like eating sweets and chocolates and will refuse them if offered.

Tristan da Cunha.

M. SHibl.

\section{INHALATION OF $\beta$-ADRENERGIC BLOCKERS BY ASTHMATICS}

SIR,-McNeill ${ }^{1}$ has reported on side-effects of propranolol ('Inderal') in asthmatics. He measured the 1-second forced expiratory volume (F.E.V.1) before and after intravenous administration of this drug. Four of his ten patients showed a pronounced fall in F.E.V.1 Zaid and Beall ${ }^{2}$ have confirmed these findings in the U.S.A. Since no reports are available on the effect of inhalation of these drugs in asthmatics, we have studied this in thirty-five young male asthmatics.

$\beta$-blocking agents ( $1 \mathrm{mg}$. per $\mathrm{ml}$.) were inhaled from aerosols produced by the 'Bird Mark 7' nebuliser (Bird Space Technology Inc., Palm Springs, California, U.S.A.). The acute effects on the ventilatory function of the asthmatics were assessed by serial measurements of the rital capacity, the F.E.V.1, and the maximum breathing capacity. Of these indices, F.E.V. ${ }_{1}$ is the most sensitive. The following drugs were tested: propranolol (Inderal) in ten patients, pronethalol ('Alderlin') in five, 'DU $21445^{\circ}$ in ten, and the dextroisomer of propranolol ('Dexinderal') in ten.

Twenty-one of the twenty-five patients who inhaled a racemic mixture of a $\beta$-blocking drug showed a sudden and pronounced fall in ventilatory function, as shown by the following mean values of F.E.V.. before and after inhalation:

$$
\text { F.E.V.1 values ( } m l .)
$$

Inhalation of $\beta$-blocking drug

$\begin{array}{llccc}\text { Drug } & & \text { Normal } & \begin{array}{c}\text { Bnhalation } \\ \text { Before }\end{array} & \text { After } \\ \text { Propranolol } & \ldots & 3270 & 3630 & 1830 \\ \text { Pronethalol } & \ldots & 3210 & 3770 & 1370 \\ \text { DU 21445 } & \ldots & 3050 & 3540 & 1950 \\ \text { Dexinderal } & . & 3130 & 3630 & 3150\end{array}$

The other four asthmatics showed no significant effects. When the dextroisomer of propranolol was given, there were no significant effects.

The precise explanation of this effect is not known. One can postulate increase of bronchial sensitivity to either endogenous or exogenous stimuli as a result of the relative inability of

1. McNeill, R. S. Lancet, 1964, ii, 1101

2. Zaid, G., Beall, G. N. New Engl. F. Med. 1966, 275, 580. bronchial smooth muscle to respond to endogenous $\beta$-adrenergic stimulation. Also it is possible for parasympathetic activity, being relatively unopposed after $\beta$-adrenergic blockade, to induce bronchospasm. It is clear, however, that bronchospasm in asthmatics is induced by the lævoisomer of propranolol, since the dextroisomer has no effect. More obscure is the reason why four out of twenty-five asthmatics showed no effect after inhalation of a racemic mixture of $\beta$-blocking agents.

I should like to thank Dr. J. A. Waycott (medical department, Imperial Chemical Industries, Ltd.) and Dr. A. Floor-Wieringa (research department, Philips-Duphar N.V.) for arranging for supplies of propranolol, pronethalol, dexinderal, and DU 21445, and for their stimulating interest and advice.

"Dr. A. Mathijsen"

Armed Forces Hospital,

Utrecht, The Netherlands.

\section{H. M. BEUMER.}

\section{HYPOTHALAMO-PITUITARY-ADRENAL FUNCTION AFTER STEROIDS}

Dr. D. FERRIMAN writes: "My co-workers and I wish to thank the Wellcome Trust for their generous support of the work we described in our article (Oct. 21, p. 856). We regret that we inadvertently left this acknowledgment out of the published version."

\section{Obituary}

\section{HUGH GREGORY GARLAND}

T.D., M.D. Leeds, F.R.C.P.

Dr. Hugh Garland, physician in charge of the department of neurology of the General Infirmary at Leeds, died on Oct. 23.

He studied medicine in the University of Leeds, and after graduating M.B. with distinction in 1926 he came to London to

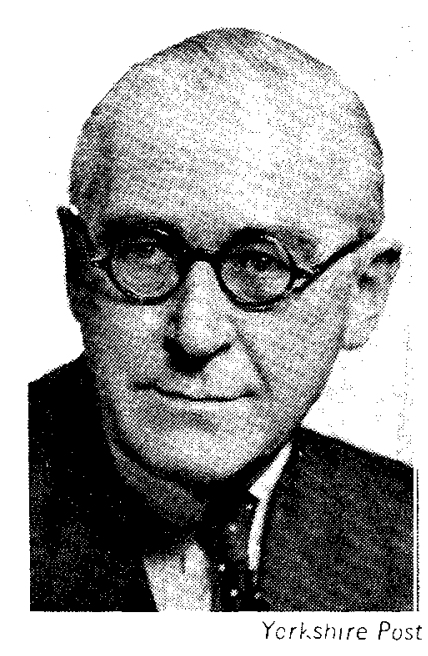

hold house appointments at the National Hospital, Queen Square, and at the Brompton. He returned to Leeds to hold resident appointments in the children's department and the pathology department at the General Infirmary before becoming medical registrar there. $\mathrm{He}$ took the M.R.C.P. in 1929 and the M.D. with distinction in 1930. At the university he held demonstratorships in toxicology, physiology, and medical pathology. He joined the staffs of the Leeds Public Dispensary and Hospital, St. James's Hospital, and the Herzl-Moser Hospital. In due course he was elected an assistant physician to the General Infirmary and to a clinical lectureship in the university. He was elected F.R.C.P. in 1939. Dr. Garland, who was a keen member of the Territorial Army, did much for neurology in the R.A.M.C., first as command neurologist in York and later as adviser in neurology, Southern Army, India. He established an excellent neurological centre for India Command at Poona and subsequently at Secunderabad. After the fall of Rangoon he drew attention to neuropathies due to nutritional deficiencies.

Soon after he returned to civilian practice he took up the charge of the Infirmary's neurology department. After 1948 he became a consultant neurologist for the region. He was a past president of the Leeds and West Riding Medico-Legal Society and of the North of England Neurological Association.

Dr. Garland leaves a wife and a daughter.

H. G. M. writes:

"Hugh's panache never concealed from his colleagues that he was one of the most gifted neurologists of his generation. 